University for Business and Technology in Kosovo

UBT Knowledge Center

UBT International Conference

2012 UBT International Conference

Nov 2nd, 9:00 AM - Nov 3rd, 5:00 PM

\title{
Current status on the causes of overruns deadline in Kosovo in highway and road constructions projects
}

\author{
Muhamet Ahmeti \\ University for Business and Technology, muhametahmeti@gmail.com
}

Follow this and additional works at: https://knowledgecenter.ubt-uni.net/conference

Part of the Architecture Commons

\section{Recommended Citation}

Ahmeti, Muhamet, "Current status on the causes of overruns deadline in Kosovo in highway and road constructions projects" (2012). UBT International Conference. 22.

https://knowledgecenter.ubt-uni.net/conference/2012/all-events/22

This Event is brought to you for free and open access by the Publication and Journals at UBT Knowledge Center. It has been accepted for inclusion in UBT International Conference by an authorized administrator of UBT Knowledge Center. For more information, please contact knowledge.center@ubt-uni.net. 


\title{
Current status on the causes of overruns deadline in Kosovo in highway and road constructions projects
}

\author{
Muhamet Ahmeti, PhD Candidate ${ }^{1}$ \\ Vienna University of Technology, Vienna; Austria \\ ${ }^{1}$ University for Business and Technology, Faculty of Architecture and Spatial Planning \\ muhamet,ahmeti@ubt-uni.net; muhametahmeti@gmail.com
}

\begin{abstract}
This paper presents the analysis of the data gathered from the interview survey revealing the process of road constructions project, cost of labour and other important factors which can result in high cost construction.

These motorway categories can employ a large variety of structural materials and can be constructed to develop a great number of structural types.

Over fifty contractors were contacted and asked for an interview survey. A total of 29 responded to participate in the interview surveys.

The main objective of this paper is to present the current status on the causes of overruns in Kosovo in highway and road projects, information can be very useful for Ministry of Infrastructure, to find main problems and gaps in road constructions projects.

Review and of questionnaires and personal contact have been focused on completed projects from the Ministry of infrastructure to determine the types of delays that have caused cost and time overruns. The information regarding the delay in construction was collected from the respondents which include various factors that directly or indirectly affected on the construction plans. There are two types of factors; economic factors and other factors, which influences the construction delay of roads and highway in Kosovo.

However, economic factor is the most important factor that contains many control variables which directly or indirectly has an influence on the quick or delayed construction of roads and highway in Kosovo.
\end{abstract}

Key words: roads and highway, Kosovo, Ministry of infrastructure 